\title{
WATER QUALITY INDEX IN AN URBAN WATERSHED
}

\author{
RAISSA C. GOMES ${ }^{1}$, REGINA M. LONGO ${ }^{1}$, FERNANDO H. S. RIBEIRO ${ }^{1}$, SUELI DO C. BETTINE ${ }^{1}$, \\ ANTONIO C. DEMANBORO ${ }^{1} \&$ ADMILSON I. RIBEIRO $^{2}$ \\ ${ }^{1}$ Urban Infrastructure Systems, PUC-Campinas, Pontifical Catholic University of Campinas, Brazil. \\ ${ }^{2}$ São Paulo University Satate - Sorocaba - SP- Brazil.
}

\begin{abstract}
This study aimed to verify the water quality of Ribeirão das Pedras (Stones River), Campinas, São Paulo, Brazil through the implementation of the Water Quality Index (WQI) and comparison with Brazilian legislation (Resolution of the National Environment Council - CONAMA 357/2005), thus being able to initiate discussions about anthropic interferences in watercourses located in urban areas. Ribeirão das Pedras is part of an urban watershed that suffered, and still suffers, from the rapid and intense urban and housing boom, finding its territorial space almost fully occupied. For the execution of this work, six sample points were defined in order to allow a discussion between the land use within their respective drainage area and the results of the WQI applications. The WQI is composed of nine parameters: dissolved oxygen, biochemical oxygen demand, nitrogen, temperature, thermotolerant coliforms, turbidity, phosphorus, $\mathrm{pH}$, and total solids. The first sample point refers to the main watercourse source, four sample points are located throughout the watershed and the last point is located in its base level, at the confluence between Ribeirão das Pedras and its main stem, Ribeirão das Anhumas (Anhumas River). The results of water quality analysis obtained based on the WQI concept were featured as 'GOOD'; however, the isolated analysis of each parameter allows to compare them with the Brazilian legislation, where it appears that none of the points meets all established quality parameters. Thus, it can be concluded that the watercourse suffers significant impacts along its course, probably derived from the use of the surrounding drainage areas.
\end{abstract}

\section{INTRODUCTION}

From all the water of the planet, only $3 \%$ is fresh, of which $75 \%$ is frozen and $10 \%$ is located in aquifers, with only $15 \%$ in liquid form distributed across the globe [1]. In addition to the restricted amount available for immediate consumption at a global level, an uneven spatial distribution is observed, a fact that causes many problems of social and economic order [2]. The quality of water resources must be observed as well. Associated with the actions of natural origin, the anthropic actions on the environment directly affect the quality of water resources, varying according to the land use, the disposal of waste and effluents and other factors that are enhanced with increased urbanization, which occur without proper planning.

The National Water Resources Policy, established by the Law No. 9,433/1997, states the watershed as the basic unit of planning and management studies [3]. The definition of watershed can be understood as an area where the rain water on it flows over a drainage network formed by water bodies and slopes toward a single exit point [4]. Thus, all pollution or contamination present in the drainage area of a given watercourse is reflected in its water quality.

Chemical and biological impacts on watercourses may be from diffuse origin (caused by the pollution carried by rain water) or from punctual origin (mainly from irregular discharges of domestic and industrial sewage without proper treatment) [5]. This work aims to verify the Water Quality Index (WQI) of Ribeirão das Pedras at six sample points on two different 
212 Environmental and Economic Impact on Sustainable Development

dates, observing the rainfall characteristics (to check seasonal interference), and the discussion of the types of land use in each sample point.

\section{METHODOLOGY}

This work was developed in Ribeirão das Pedras, located in the city of Campinas, São Paulo, limited by the coordinates 7,478,588 meters and 7,469,156 meters $\mathrm{S}$ and 282,277 meters and 289,826 meters W. The subtropical climate, marked by wet periods between the months of October and April and dry ones from May to September [6], has direct influence on the quality of the water resources in this region; therefore, samples were taken on two different dates (October 2015 and January 2016).

Within the watershed were set six water sample points distributed from the source to the base level, as shown in Fig. 1. The watershed is currently quite anthropized, where most of

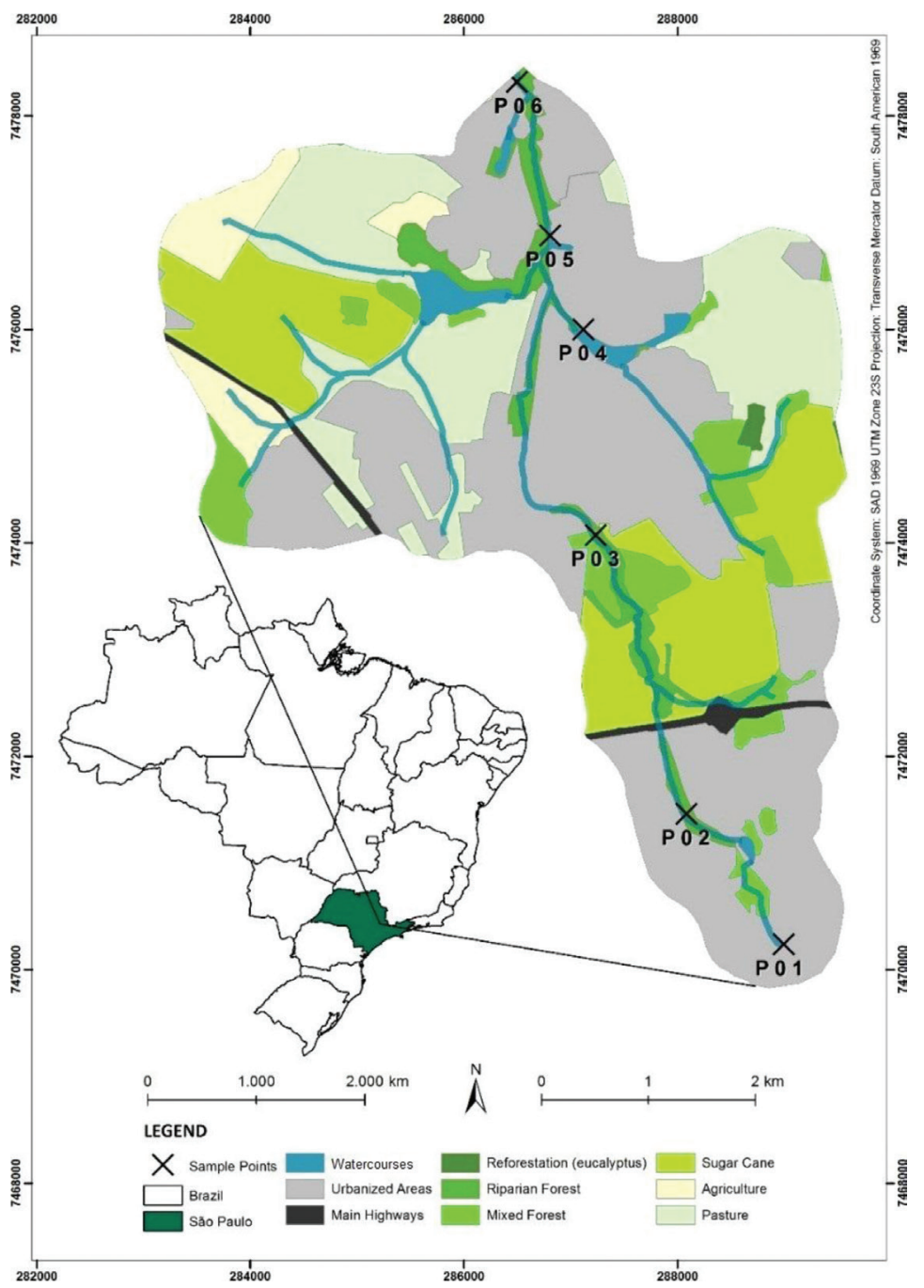

Figure 1: Location, land use, and cover and sample points in the Ribeirão das Pedras watershed, Campinas, São Paulo, Brazil. 
its territory is occupied by impervious areas with low soil quality [7], and its original vegetation is significantly changed [8-10]. The first sample point, P01, is located at the source of the watercourse, under the coordinates 7,470,195 meters $\mathrm{S}$ and 288,966 meters W, in a densely urbanized district. The second point, P02, is located approximately $1.8 \mathrm{~km}$ from P01, in a densely urbanized area as well, under the coordinates 7,471,513 meters $\mathrm{S}$ and 288,040 meters $\mathrm{W}$, next to a shopping mall. The third point, P03, was chosen considering its location immediately after Dom Pedro highway and an area of sugarcane cropping, under the coordinates 7,474,095 meters S and 287,768 meters W. The fourth point, P04, under the coordinates $7,475,978$ meters $\mathrm{S}$ and 287,132 meters $\mathrm{W}$, is also located in a densely urbanized area, near an ecological park. The fifth point, P05, is located at the crossing of the watercourse with Rhodia Road, between areas of intense urbanization, under the coordinates 7,476,722 meters $\mathrm{S}$ and 286,804 meters $\mathrm{W}$. The sixth point, P06, located in an urbanized area as well, under the coordinates 7,478,327 meters $\mathrm{S}$ and 286,501 meters $\mathrm{W}$, is located around $50 \mathrm{~m}$ from the studied river base level with Ribeirão das Anhumas.

The performed sampling obey the standard established by the Sample Collection and Preservation National Guide from CETESB - Environmental Company of the State of São Paulo [11]. The parameters of temperature and dissolved oxygen were measured at the location of each sample to minimize potential errors and value changes due to its physical and chemical properties loss.

The analysis of the defined parameters for obtaining the WQI, as proposed by CETESB, were performed according to the methodologies from Table 1. Each parameter has a quality value $q$, variable between 0 and 100 , obtained from the standardization curve of the quality graphic in function of the analysis result. The obtained values were weighted according to their respective parameter weight $w$ (Table 1). The calculation of the WQI is the sum of the weighted product of the nine parameters (eqn 1). This value is rated as shown in Table 2.

Table 1: Analyzed parameters and methodologies [11-13].

\begin{tabular}{llcc}
\hline Parameters & \multicolumn{1}{c}{ Analysis Methodology } & Weight & \multicolumn{1}{c}{ Source } \\
\hline $\begin{array}{l}\text { Dissolved oxygen (DO) } \\
\text { Thermotolerant } \\
\text { coliforms (TTC) }\end{array}$ & Electrometric (oximetry) & 0.17 & CETESB (2011) \\
pH & Multiple tubes & 0.15 & BRASIL (2009) \\
$\begin{array}{l}\text { Biochemical oxygen } \\
\text { demand (BOD }\end{array}$ 5otentiometer & $\begin{array}{l}\text { Oxymetry and incubation } \\
\text { Temperature }\end{array}$ & 0.12 & BRASIL (2009) \\
Nitrogen & $\begin{array}{l}\text { Digital thermometer } \\
\text { Digestion and distillation } \\
(\text { Kjeldahl) }\end{array}$ & 0.10 & APHA (2005) \\
Phosphorus & $\begin{array}{l}\text { UV-visible, ascorbic acid } \\
\text { method }\end{array}$ & 0.10 & APHA (2005) \\
Turbidity & $\begin{array}{l}\text { Turbidimeter } \\
\text { Gravimetry }\end{array}$ & 0.08 & BRASIL (2009) \\
Total solids & 0.08 & APHA (2005) \\
\hline
\end{tabular}


214 Environmental and Economic Impact on Sustainable Development

Table 2: WQI rating.

\begin{tabular}{lc}
\hline CATEGORY & RATE \\
\hline EXCELLENT & $79<\mathrm{IQA} \leq 100$ \\
GOOD & $51<\mathrm{IQA} \leq 79$ \\
MEDIUM & $36<\mathrm{IQA} \leq 51$ \\
BAD & $19<\mathrm{IQA} \leq 36$ \\
VERY BAD & IQA $\leq 19$ \\
\hline
\end{tabular}

Source: Adapted from CETESB, 2015 [14].

$$
\text { (a) } \mathrm{WQI}=\prod_{i=1}^{n} q_{i}^{w_{i}} \quad \text { (b) } \sum_{i=1}^{n} w_{i}=1
$$

Equation 1: WQI calculus [1].

where:

WQI: Water Quality Index, a number between 0 and 100;

n: number of parameters entering the calculation of the WQI;

$\mathbf{q}_{\mathbf{i}}$ : quality of the i-th parameter, a number between 0 and 100 , obtained from its 'mean curve of quality variation', due to its concentration or measure; and

$\mathbf{w}_{\mathbf{i}}$ : weight corresponding to the $\mathrm{i}$-th parameter, a number between 0 and 1 assigned according to their importance to the overall conformance to quality.

Although the result of the WQI gathers the nine parameters defined as most important, the individual analysis of each one is essential and may show local variations suffered [14]. Therefore, it is necessary to know each parameter - what it indicates, its main source (natural and/or anthropic), and the environmental impacts.

\section{RESULTS AND DISCUSSION}

Figure 2 shows the results obtained for the analyzed water quality parameters (dissolved oxygen, biochemical oxygen demand, nitrogen, temperature, thermotolerant coliforms, turbidity, phosphorus, $\mathrm{pH}$, and total solids) in the six sample points. It can be observed that some parameters do not meet the established by CONAMA resolution (357/05) [15]. For example, the dissolved oxygen value is below the minimum established, which is $5.00 \mathrm{mg} / \mathrm{L}$, while the biochemical oxygen demand is demand oxygen in accordance with the established, which maximum is $5.00 \mathrm{mg} / \mathrm{L}$. Values that low, also an indicator of the presence of organic matter [16], are mortal for the aquatic fauna that are more sensitive to changes. This resolution does not define threshold values for temperature, but temperature is a limiting factor for the amount of dissolved oxygen in water [17]. These parameters are inversely related, once the temperature increases, a drop in the concentration of dissolved oxygen is observed. The maximum value obtained for turbidity ( $34.07 \mathrm{NTU}$ ) is below the maximum established by legislation (100 NTU), which indicates that the resistance to the passage of light is not impaired, that is, photosynthetic activity (which is also a source of oxygen in the water) finds proper conditions to happen [17]. Nitrogen is above the maximum allowed by the resolution, which is $3.7 \mathrm{mg} / \mathrm{L}$, at all points except at the source, which, despite being in a densely urbanized area, does not come out of the established. P03 stands out with the value of $89.22 \mathrm{mg} / \mathrm{L}$ (Oct 2015) and this 
Environmental and Economic Impact on Sustainable Development 215

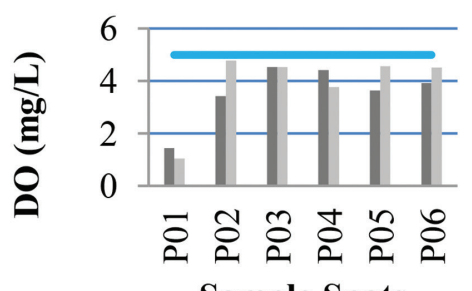

Sample Spots
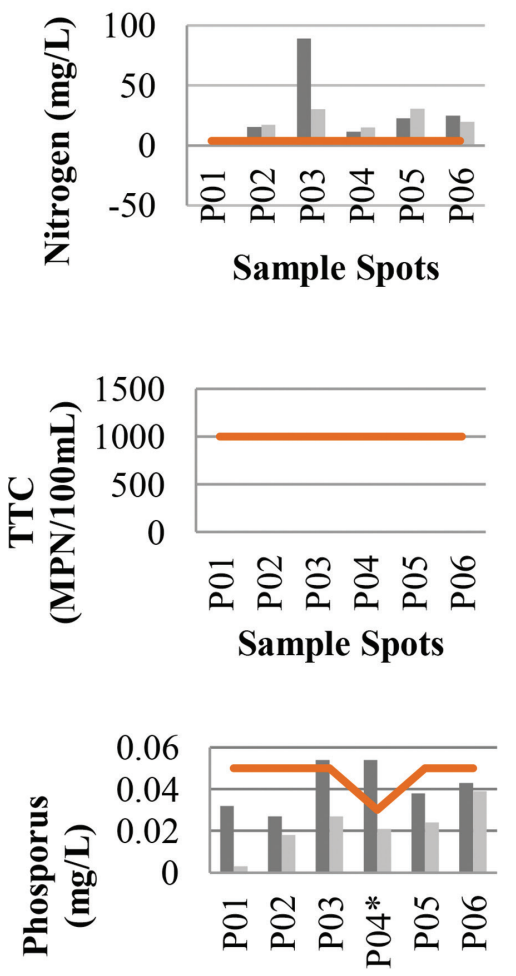

Sample Spots

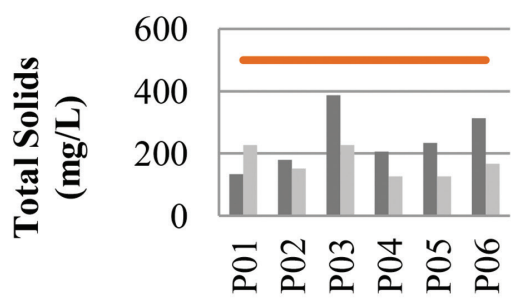

Sample Spots
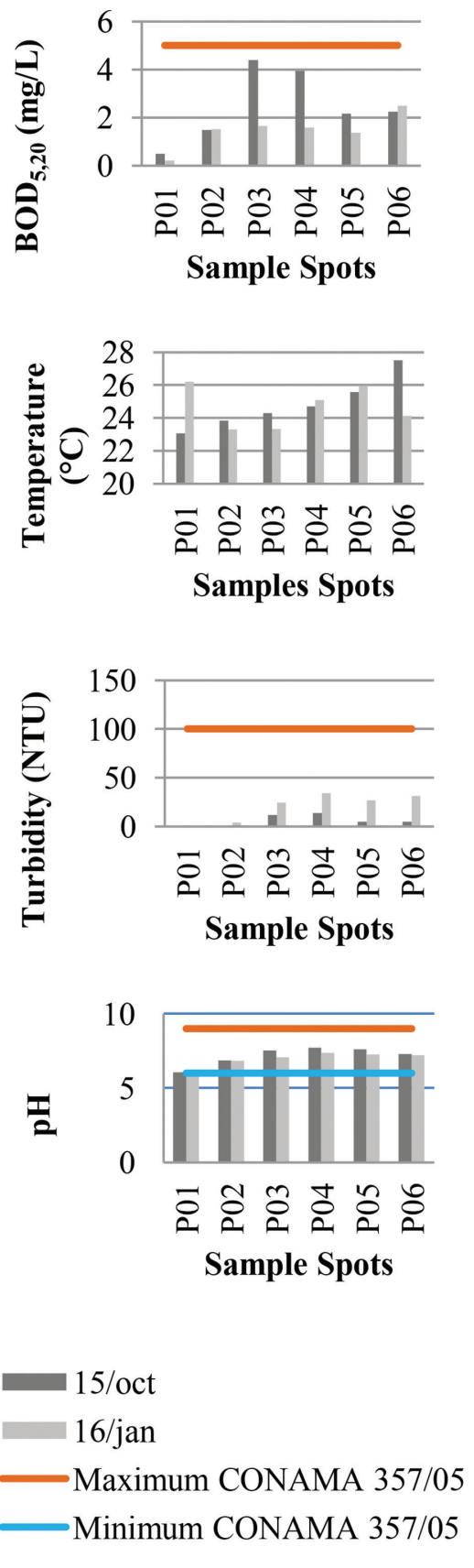

Figure 2: Results obtained for the nine parameters of the sample points through Ribeirão das Pedras watershed, Campinas, São Paulo, Brazil. 
216 Environmental and Economic Impact on Sustainable Development

Table 3: Ribeirão das Pedras WQI.

\begin{tabular}{lll}
\hline Sample Spots & October 2015 & January 2016 \\
\hline P01 & 76 (GOOD) & 74 (GOOD) \\
P02 & $74($ GOOD) & 79 (GOOD) \\
P03 & 66 (GOOD) & 73 (GOOD) \\
P04 & 75 (GOOD) & 74 (GOOD) \\
P05 & $74($ GOOD) & 75 (GOOD) \\
P06 & 73 (GOOD) & 71 (GOOD) \\
\hline
\end{tabular}

may be associated with the fact that it is under the influence of effluent discharge close to a shopping mall and an area of sugarcane cropping, where exposed soil is observed, which is easily carried away by rain and/or wind to the watercourse.

Phosphorus is also above the maximum allowed by the resolution, once expressive results are observed. The marking $\left(^{*}\right)$ in $\mathrm{P} 04$ for this parameter is observed only in this point due the CONAMA resolution, that assigns threshold values for lentic (maximum $0.3 \mathrm{mg} / \mathrm{L}$ ) and lotic (maximum 0.5 mg/L) environments; once P04 is considered lentic and, therefore, differentiated. P03 also has a higher concentration than the allowed level for phosphorus; both results refer to the collection held in October 2015. The values established by the Brazilian legislation for $\mathrm{pH}(6.0-9.0)$, thermotolerant coliforms $(<1,000 / 100 \mathrm{~mL})$ and total solids $(<500.00 \mathrm{mg} / \mathrm{L})$ parameters lead to the conclusion that the values found are in accordance. The calculation of the WQI resulted in the values shown in Table 3, where it is observed that for all the points and in both observed dates, the various WQI obtained were rated as 'GOOD'.

\section{CONCLUSION}

The analysis of the results concluded that at the watershed studied, the anthropic interference promoted changes in water quality parameters, such as dissolved oxygen, biochemical oxygen demand, nitrogen and phosphorus, the most because of the land use. It was also noted that although the various WQI parameters calculated were rated as 'GOOD' at all points, those rates are not a realistic indicator of quality, once the isolated parameters analysis showed that they are, in general, far from the levels recommended by legislation.

Then, once the land use directly interferes in isolated parameters, an individualized discussion of the results and a survey of the possible disturbances are essential to study urban watersheds in order to improve their water quality.

These findings emphasize the urgency for the conservation of the urban watercourses, assuming they are tributaries of major rivers and so on. It is also noteworthy that availability of water in quantity is not enough when its qualitatively unavailable.

\section{REFERENCES}

[1] Tundisi, J.G., Recursos hídricos. Instituto Nacional de Ecologia, São Carlos/SP, 2003.

[2] Tundisi, J.G., Water resources in the future: problems and solutions. Estudos avançados, 22(63), pp. 7-16, 2008. http://dx.doi.org/10.1590/S0103-40142008000200002

[3] Brasil. Lei $n^{\circ}$ 9.433, de 8 de janeiro de 1997. Institui a Política Nacional de Recursos Hídricos, cria o Sistema Nacional de Gerenciamento de Recursos Hídricos, regulamen- 
ta o inciso XIX do art. 21 da Constituição Federal, e altera o art. $1^{\circ}$ da Lei $n^{\circ} 8.001$, de 13 de março de 1990, que modificou a Lei n ${ }^{\circ} 7.990$, de 28 de dezembro de 1989. Diário Oficial da União, seç. 1, p. 470, Brasília, 09 de janeiro de 1997.

[4] Silveira, A.L.L., Ciclo hidrológico e a bacia hidrográfica. In Hidrologia: ciência e aplicação. Organizado por Tucci, C. E. M.; Silveira, A. I. I. et al., Porto Alegre: Editora da UFRGS/ABRH, ed. 4, reimp. 5, pp. 35-51, 2013.

[5] Nascimento, N.O., Heller, L., Ciência, tecnologia e inovação na interface entre as áreas de recursos hídricos e saneamento. Engenharia Sanitária e Ambiental, 10(1), pp. 3648, 2005. http://dx.doi.org/10.1590/S1413-41522005000100005

[6] Muller, M.I., Fauna helmintológica das espécies amazônicas de peixes (Cichla monoculus e Brycon amazonicus) introduzidas nas lagoas da Fazenda Rio das Pedras, Campinas/SP. Dissertação (mestrado). Universidade Estadual de Campinas, Instituto de Biologia. Campinas/SP, p. 68, 2008.

[7] Damame, D.B., Longo, R.M., Ribeiro, A.I., Fengler, F.H., Variation of the anthropic vulnerability in Ribeirão das Pedras watershed in Campinas/SP - Brazil. Geophysical Research Abstracts, 17, p. 577, 2015.

[8] Etto, T.L., Longo, R.M., Arruda, D.R., Invenzioni, R., Cereda Junior, A., Ecologia de paisagem de remanescentes florestais localizados na bacia hidrográfica do ribeirão das pedras - Campinas/SP. Revista Árvore (Impresso), 37, pp. 1063-1071, 2013. http://dx.doi.org/10.1590/S0100-67622013000600008

[9] Longo, R.M., Zangirolami, G.F., Yamaguchi, C.S., Demamboro, A.C., Bettine, S.C., Ribeiro, A.I., Impacts of agricultural activities in remaining forest: Campinas/SP, Brazil. WIT Transactions on Ecology and the Environment (Print), 170, p. 15, 2013. http://dx.doi.org/10.2495/FENV130021

[10] Longo, R.M., Reis, M.S., Yamaguchi, C.S., Demamboro, A.C., Bettine, S.C., Ribeiro, A.I. \& Medeiros, G.S., Indicators of soil degradation in urban forests: physical and chemical parameters. WIT Transactions on Ecology and the Environment (Print), 162, pp. 497-506, 2012. http://dx.doi.org/10.2495/EID120431

[11] CETESB. Guia nacional de coleta e preservação de amostras: água, sedimento, comunidades aquáticas e efluentes líquidos. Organizadores: Carlos Jesus Brandão, et al. São Paulo: CETESB; Brasília: ANA, p. 326, 2011.

[12] Brasil. Fundação Nacional de Saúde. Manual prático de análise de água. $3^{\mathrm{a}}$ ed. rev. Brasília: Fundação Nacional de Saúde, p. 144, 2009.

[13] APHA - American Public Health Association. Standard Methods for the Examination of Water and Wastewater. Washington, ed. 21, 2005.

[14] CETESB. Qualidade das águas superficiais no estado de São Paulo - Apêndice C. São Paulo, 2015.

[15] Brasil. Resolução ${ }^{\circ}$ 357, de 17 de março de 2005. Dispõe sobre a classificação dos corpos de água e diretrizes ambientais para o seu enquadramento, bem como estabelece as condições e padrões de lançamento de efluentes. Diário Oficial da União, pp. 58-63, 18 de março de 2005.

[16] Von Sperling, M., Introdução à qualidade das águas e ao tratamento de esgotos. ed. 3. Belo Horizonte: Departamento de Engenharia Sanitária e Ambiental - DESA; Universidade Federal de Minas Gerais, 2007.

[17] Oram, B., Water Research Center. Dissolved oxygen in water. Dallas/PA. 2016. Avaiable at: http://www.water-research.net/index.php/dissovled-oxygen-in-water 